\title{
Redundant Catecholamine Signaling Consolidates Fear Memory via Phospholipase C
}

\author{
Ming Ouyang, ${ }^{1}$ Matthew B. Young, ${ }^{1}$ Melissa M. Lestini, ${ }^{2}$ Keith Schutsky, ${ }^{1}$ and Steven A. Thomas ${ }^{1}$ \\ ${ }^{1}$ Department of Pharmacology and Neuroscience Graduate Group, Perelman School of Medicine, University of Pennsylvania, Philadelphia, Pennsylvania \\ 19104-6084, and 2Division of Neonatology, Children's Hospital of Philadelphia, Philadelphia, Pennsylvania 19104
}

\begin{abstract}
Memories for emotionally arousing experiences are typically vivid and persistent. The recurrent, intrusive memories of traumatic events in post-traumatic stress disorder (PTSD) are an extreme example. Stress-responsive neurotransmitters released during emotional arousal are proposed to enhance the consolidation of fear memory. These transmitters may include norepinephrine and epinephrine (NE/E) because stimulating $\beta$-adrenergic receptors shortly after training can enhance memory consolidation. However, mice lacking NE/E acquire and consolidate fear memory normally. Here, we show by using pharmacologic and genetic manipulations in mice and rats that NE/E are not essential for classical fear memory consolidation because signaling by the $\beta_{2}$-adrenergic receptor is redundant with signaling by dopamine at the $\mathrm{D}_{5}$-dopaminergic receptor. The intracellular signaling that is stimulated by these receptors to promote consolidation uses distinct $\mathrm{G}$ proteins to redundantly activate phospholipase $\mathrm{C}$. The results support recent evidence indicating that blocking $\beta$-adrenergic receptors alone shortly after trauma may not be sufficient to prevent PTSD.
\end{abstract}

\section{Introduction}

The basolateral nuclei of the amygdala (BLA) is a brain region critical to the consolidation of fear memory (Pape and Pare, 2010). Changes in neuromodulatory signaling in the BLA during emotional arousal are believed to underlie the powerful and persistent consolidation of long-term fear memory. Neuromodulators such as norepinephrine and epinephrine $(\mathrm{NE} / \mathrm{E})$ that are released during fearful or traumatic events can promote memory consolidation for such experiences. For example, stimulating $\beta$-adrenergic receptors by infusing NE or $\beta$-adrenergic selective agonists into the BLA shortly after instrumental fear conditioning enhances long-term memory (McGaugh and Roozendaal, 2002).

In contrast, a requirement for $\beta$-adrenergic signaling in fear memory consolidation is less clear. In one study, BLA infusion of $\beta$-adrenergic receptor antagonists impaired consolidation of instrumental fear (Gallagher et al., 1977). However, results from

Received Oct. 17, 2011; revised Nov. 18, 2011; accepted Dec. 9, 2011.

Author contributions:M.O., M.B.Y.,M.M.L. and S.A.T. designed research;M.O., M.B.Y., M.M.L. and K.S. performed research; M.O., M.B.Y., M.M.L., K.S. and S.A.T. analyzed data; and S.A.T. and M.B.Y. wrote the paper.

This work was supported by Department of Defense GrantPT075099 and NIH Grant5R01MH063352 to S.A.T. We thank Dainippon Sumitomo Pharma (Osaka, Japan) for their generous gift of L-threo-3,4-dihyroxyphenylserine used to rescue Dbh-/ - mice prenatally, and B. Kobilka (Stanford University), M. Xu (University of Chicago), and D. Sibley (National Institutes of Health) for providing stock for the $\beta$ receptor and DA receptor $\mathrm{KO}$ mouse lines.

The authors declare no conflict of interest.

Correspondence should be addressed to Dr. Steven Thomas, Department of Pharmacology, Perelman School of Medicine, University of Pennsylvania, 103 John Morgan Building, 3620 Hamilton Walk, Philadelphia, PA 191046084. E-mail: sathomas@upenn.edu.

M. M. Lestini's present address: Division of Neonatology, Department of Pediatrics, Hackensack University Medical Center, 30 Prospect Avenue, Hackensack, NJ 07601.

K. Schutsky's present address: Department of Microbiology and Immunology, Center for Neurovirology, 1020 Locust Street, Jefferson Alumni Hall, Room 465, Philadelphia, PA 19107.

DOI:10.1523/JNEUROSCI.5231-11.2012

Copyright $\odot 2012$ the authors $\quad 0270-6474 / 12 / 311932-10 \$ 15.00 / 0$ other studies suggest that $\beta$ signaling is not required for consolidation of instrumental fear (Izquierdo and Dias, 1983; Izquierdo et al., 1992). Negative results have also been reported for classical fear. Infusing a $\beta$-adrenergic receptor antagonist into the BLA shortly before or immediately after classical fear conditioning does not impair consolidation (Miserendino et al., 1990; Debiec and LeDoux, 2004). Furthermore, instrumental and classical fear memory consolidation are normal in mice completely lacking NE/E (Thomas and Palmiter, 1997; Murchison et al., 2004) or harboring a targeted disruption of either the $\beta_{1}$ - or $\beta_{2}$-adrenergic receptor gene (Schutsky et al., 2011).

A potential resolution to the observation that the adrenergic system can influence, but is not required for, consolidation is that there is redundancy between the adrenergic system and another neurotransmitter system. In redundancy, the loss of a single system will have no effect on consolidation. However, interfering with two relevant but redundant systems simultaneously could have considerable effect. Classically, $\beta$-adrenergic receptors couple to $G_{s}$ proteins that act to stimulate adenylyl cyclase (AC) and elevate intracellular levels of CAMP, a second messenger required in the BLA for fear memory consolidation (Schafe and LeDoux, 2000). It is through $\mathrm{G}_{\mathrm{s}}$ and cAMP that $\beta$ receptors are currently proposed to enhance synaptic plasticity and memory consolidation (Sara, 2009; Tully and Bolshakov, 2010).

For this study, we considered whether DA might serve as a stress-responsive system that acts in a redundant manner with $\mathrm{NE} / \mathrm{E}$ in promoting consolidation. Like NE/E, extracellular levels of DA are elevated for minutes following fear conditioning (Inglis and Moghaddam, 1999; Anstrom and Woodward, 2005). Like $\beta$ receptors, the $D_{1}$ class of DA receptors, consisting of the $D_{1}$ and $D_{5}$ receptors $\left(D_{1,5}\right)$, can couple to the $G_{s}$ class of $G$ proteins and elevate cAMP (Sibley and Monsma, 1992), providing an oppor- 
tunity for redundant signaling between these two classes of catecholamine receptors. Here, we use genetic and pharmacologic approaches in mice and rats to demonstrate that DA and NE/E have redundant roles in the BLA for the consolidation of classical fear memory. Surprisingly, we found that the signaling by these neuromodulators that is critical for consolidation converges on the activation of phospholipase $\mathrm{C}$.

\section{Materials and Methods}

Animals. Wild-type, $D b h^{+-}, D b h^{-1-}, A d r b 1^{-1-}\left(\beta_{1} \mathrm{KO}\right)$, Adrb2 $2^{-1-}$ $\left(\beta_{2} \mathrm{KO}\right)$, and $\operatorname{Drd1} 1^{-1-}\left(\mathrm{D}_{1} \mathrm{KO}\right)$ mice were on a hybrid $129 / \mathrm{Sv} \times$ C57BL/6 background, while Drd5 ${ }^{-1-}\left(\mathrm{D}_{5} \mathrm{KO}\right)$ mice were on a C57BL/6 background (Xu et al., 1994; Thomas et al., 1995; Rohrer et al., 1996; Chruscinski et al., 1999; Holmes et al., 2001). Mice were generated by mating either heterozygotes or homozygotes, and genotype was determined by PCR. The prenatal loss of $\mathrm{Dbh} \mathrm{h}^{-1-}$ mice was rescued as previously described (Ouyang et al., 2004). No significant differences were found by gender or parental genotype so data were combined. Female Fischer 344 rats (Harlan) were 3-4 weeks old upon arrival. Animals were maintained on ad libitum food and water and a $12 \mathrm{~h}$ light/dark cycle, with lights on beginning at 7:00 A.M. Animals were housed in small, quiet rooms for at least 3 weeks before studies began. Mice were 3-6 months old and rats were 8-11 weeks old when tested. Studies were performed during the light phase, with most experiments taking place between 9:00 A.M. and 5:00 P.M. Studies were in accordance with NIH guidelines and had the approval of the Institutional Animal Care and Use Committee at the University of Pennsylvania.

Classical fear conditioning. Adjacent to the training room, animals were placed in pairs (mice) or singly (rats) into opaque plastic holding buckets (12 cm diameter) with bedding and lids for 30-60 min before being manipulated further. Animals were given two 3 min preconditioning handling sessions over $2 \mathrm{~d}$ in the training room. Saline was injected at the end of handling each day. For conditioning, animals were placed in the training apparatus (ENV-010MC with ENV-414S, Med Associates) for 2 min, after which an $84 \mathrm{~dB}, 4.5 \mathrm{kHz}$ tone was activated for $30 \mathrm{~s}$. Two seconds before the end of the tone, a $2 \mathrm{~s}$ footshock was delivered $(1 \mathrm{~mA}$ for mice, $1.7 \mathrm{~mA}$ for rats). The animal was removed from the apparatus and injected $30 \mathrm{~s}$ after shock, and then returned to its home cage. The apparatus was cleaned with Versa-Clean (Thermo Fisher Scientific) between subjects. Experiments examining enhancement of consolidation in mice were conducted identically except that a $0.4 \mathrm{~mA}$ footshock was used. Pseudoconditioning was similar to conditioning except that animals received the $2 \mathrm{~s}, 1 \mathrm{~mA}$ footshock immediately after being placed in the conditioning apparatus, while activation of the $30 \mathrm{~s}$ tone occurred at the normal time $2 \mathrm{~min}$ later. Contextual fear was tested for $5 \mathrm{~min}$ in the conditioning apparatus in the absence of the tone. Cued fear was tested in a Plexiglas cylinder $(21 \mathrm{~cm}$ diameter, $24 \mathrm{~cm}$ tall $)$ with green wire grid floor and vertical green and white wall stripes $240^{\circ}$ around, and was cleaned with lemon-scented Ajax between subjects. After 2 min, the training tone was turned on for $3 \mathrm{~min}$. Percentage freezing was estimated by scoring the presence or absence of nonrespiratory movement every $5 \mathrm{~s}$. Tests were conducted $1 \mathrm{~d}$ after training.

Instrumental fear conditioning. Animals were handled as described above. Training consisted of placing an animal in the lighted chamber of the apparatus used for classical conditioning and timing its latency to fully enter (except for the tail) the dark chamber. Once the animal entered the dark chamber, the retractable partition separating the two chambers was lowered and a footshock was delivered for $2 \mathrm{~s}(0.35 \mathrm{~mA})$. The animal was removed from the apparatus and injected $15 \mathrm{~s}$ after shock, and then returned to its home cage. Animals that did not enter the dark chamber after $100 \mathrm{~s}$ during conditioning were excluded $(<4 \%$ of mice, independent of genotype). Testing was identical to training except that no shock was delivered and the partition remained up. Latencies to enter the dark chamber were recorded. If an animal did not enter the dark chamber within $10 \mathrm{~min}$, it was returned to its cage and assigned a latency of $10 \mathrm{~min}$. Tests were conducted $1 \mathrm{~d}$ after training.

Drugs. SCH 23390 HCl, ecopipam (SCH 39166 HBr), SKF 38393 HBr, SKF 83959 HBr, SKF 83822 HBr, (-)-propranolol HCl, CGP 20172A
$\mathrm{HCl}$, ICI $118,551 \mathrm{HCl}$, procaterol $\mathrm{HCl}$, pertussis toxin, edelfosine (all Tocris Bioscience) and m-3M3FBS (Sigma) were administered intraperitoneally or infused into the BLA immediately after training. The phospholipase C (PLC) inhibitor U73122 could not be used in these studies because its delivery requires high percentage organic vehicles that disrupt memory consolidation on their own. Xamoterol hemifumarate (Tocris Bioscience) was administered intraperitoneally $60 \mathrm{~min}$ before testing contextual fear in $\mathrm{Dbh}^{-1-}$ mice to rescue memory retrieval (Murchison et al., 2004). Drugs were dissolved in $0.9 \%$ saline (SKF compounds and procaterol also contained $0.1 \mathrm{mg} / \mathrm{ml}$ ascorbic acid, $\mathrm{pH} 7.4$, Sigma). Vehicle was saline with or without $0.1 \mathrm{mg} / \mathrm{ml}$ ascorbic acid. Systemic injection volumes were $10 \mu \mathrm{l} / \mathrm{g}$ body weight.

CNS infusion. Two guide cannulae mounted on a base plate (C315GS system, Plastics One) were implanted under pentobarbital anesthesia (72.5 mg/kg) using a stereotax (SAS75/EM40M, Cartesian Research). The guides were placed $1.25 \mathrm{~mm}$ posterior to bregma and $3.5 \mathrm{~mm}$ bilateral for BLA infusions. The guide and dummy cannulae projected $3 \mathrm{~mm}$ below the base plate. Habituation of the animals to the investigator and the infusion procedure began a couple of days later with a 3 min handling session followed by 3 min of immobilization (gently holding the nape of the neck and body) that mimicked infusion. Five handling sessions were given, with two of them being on the $2 \mathrm{~d}$ immediately preceding training and the final one being $1 \mathrm{~h}$ before training. Immediately after training, mice were infused bilaterally using injection cannulae that extended 2.8 $\mathrm{mm}$ below the tip of the guide cannulae. Infusion was $0.2 \mu \mathrm{l} / \mathrm{side}$ at 0.08 $\mu \mathrm{l} / \mathrm{min}$, with the injection cannulae being left in place for $30 \mathrm{~s}$ before the mouse was returned to its home cage. Because studies indicate that the effects of PTx are best evaluated $3 \mathrm{~d}$ after infusion, PTx was infused into the BLA 3 d before training (Goh and Pennefather, 1989; Stratton et al., 1989). For sites adjacent to the BLA, infusions were displaced $0.75 \mathrm{~mm}$ from the BLA coordinates in the direction indicated. As a result, dorsal was in the posterior striatum, ventral was near the ventral piriform cortex, medial was at the central/medial amygdala border, lateral was in the dorsal piriform cortex, rostral was in the extreme anterior amygdala, and caudal was in the extreme posterior amygdala.

$\mathrm{IP}_{3}$ levels. Mice were anesthetized with $\mathrm{CO}_{2}$, killed by cervical dislocation and brains were rapidly removed, frozen in isopentane on dry ice and stored at $-80^{\circ} \mathrm{C}$. Two frozen coronal sections $(400 \mu \mathrm{m})$ that contained the BLA were cut by cryostat (HM505E, Microm) from each mouse, and a $0.5 \mathrm{~mm}$ diameter punch of BLA tissue was collected bilaterally from each slice. The four punches per mouse were pooled and homogenized on ice with three $2 \mathrm{~s}$ pulses ( $5 \mathrm{~s}$ interval) in $125 \mu \mathrm{l}$ of $4 \%$ perchloric acid using a Sonic Dismembrator 100 set on level 3 (Thermo Fisher Scientific). After 15 min on ice, samples were stored overnight at $-80^{\circ} \mathrm{C}$. The next day samples were centrifuged at $4^{\circ} \mathrm{C}$ and $2000 \times g$ for 15 min, and the pellet was stored at $-80^{\circ} \mathrm{C}$ for subsequent Bradford assay to determine total protein. Supernatants were neutralized on ice with $10 \mathrm{M}$ $\mathrm{KOH}$ (to precipitate the perchloric acid) and centrifuged at $4^{\circ} \mathrm{C}$ and $2000 \times g$ for $15 \mathrm{~min}$. Supernatant $(100 \mu \mathrm{l})$ was then used in the $\left[{ }^{3} \mathrm{H}\right]-\mathrm{IP}_{3}$ radioreceptor assay (PerkinElmer) according to instructions. Pilot experiments indicated that $\mathrm{IP}_{3}$ levels were elevated $30 \mathrm{~min}$ after systemic agonist injection, but not at 15,22 , or $35 \mathrm{~min}$.

Statistics. Data were analyzed with Statistica 9.1 (StatSoft) using oneor two-way ANOVA with $\alpha=0.05$. The Bartlett Chi-square test was used to analyze homogeneity of variances. Post hoc comparisons were made using Duncan's range test. In Figures 1-9, data are presented as mean \pm SE. Comparisons marked as significant are to the reference group except where indicated.

\section{Results}

Redundancy between $D_{1 / 5}$-dopaminergic and $\boldsymbol{\beta}_{2}$-adrenergic signaling

To determine whether signaling by DA might be redundant with that for NE/E, we first examined the effect of the $\mathrm{D}_{1,5}$ antagonist SCH 23390 (SCH) on memory consolidation when administered immediately after classical fear conditioning in wild-type mice and mice completely lacking NE/E (Iorio et al., 1983). Mice that lacked NE/E were homozygous for targeted disruption of the 

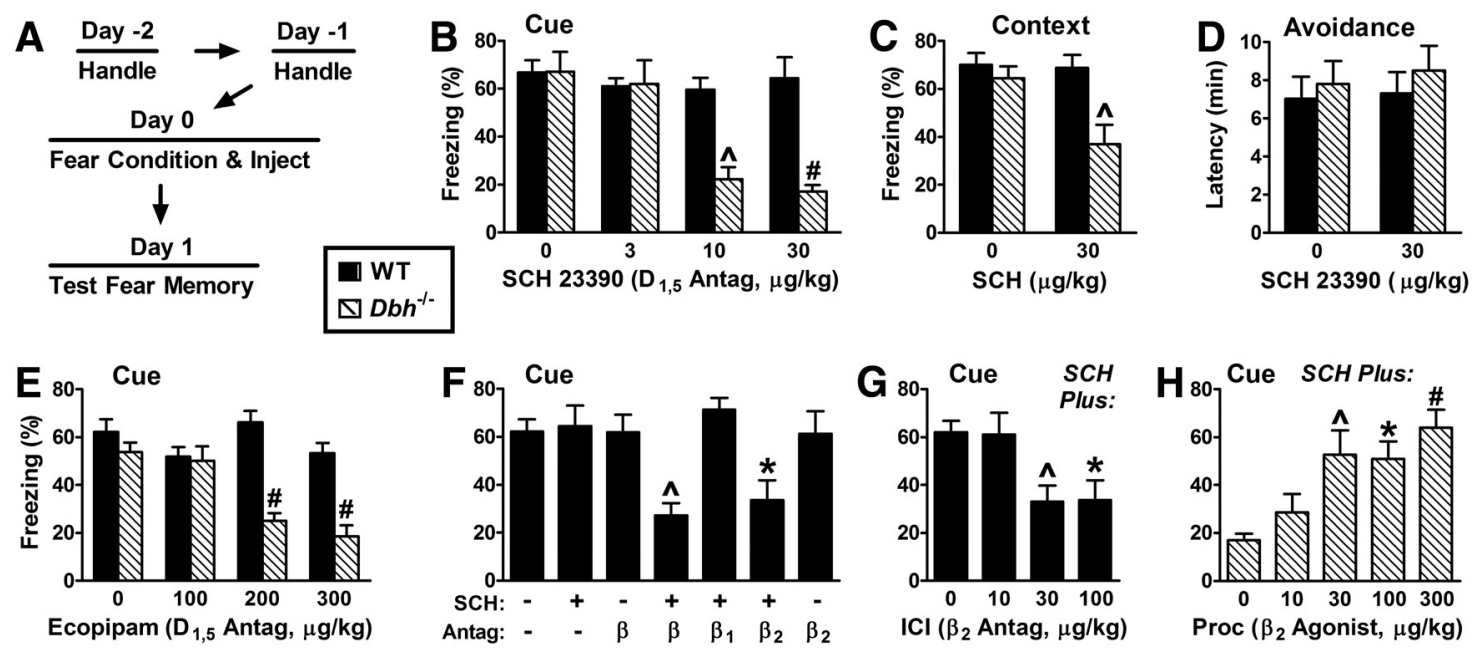

Figure 1. $\quad D_{1 / 5}$-dopaminergic signaling is redundant with $\beta_{2}$-adrenergic signaling for fear memory consolidation. $\boldsymbol{A}$, General time line for fear memory experiments, indicating that drugs were administered immediately after conditioning and testing was performed the next day. More extensive pretraining handling was performed for CNS infusion experiments. For this figure, conditioning was with intense shock ( $1 \mathrm{~mA}) . \boldsymbol{B}-\boldsymbol{E}, \mathrm{AD}_{1 / 5}$ receptor antagonist (SCH 23390 or ecopipam) was injected intraperitoneally. $\boldsymbol{B}$, Cued fear test. $p=0.0001$ for the main effect of dose; $p<0.0001$ for the main effect of genotype; and $p=0.0004$ for the interaction of dose and genotype (6/group). $\boldsymbol{C}$, Contextual fear test. The $\beta_{1}$-adrenergic receptor agonist xamoterol ( $3 \mathrm{mg} / \mathrm{kg}$ ) was administered 60 min before testing contextual fear in $D b h^{-1-}$ mice to rescue their contextual memory retrieval deficit (Murchison et al., 2004). $p=0.027 \mathrm{for}$ the main effect of treatment; $p=0.005$ for the main effect of genotype; and $p=0.039$ for the interaction of treatment and genotype (6/group). $D$, Cued fear test. $p=0.0006$ for the main effect of dose; $p<0.0001$ for the main effect of genotype; and $p=0.0003$ for the interaction of dose and genotype (5-8/group). $\boldsymbol{E}$, Instrumental fear test. Main effects and their interaction were not significant (7-8/group). $\boldsymbol{F}, \mathbf{G}$, Cued fear test. The $\mathbf{D}_{1 / 5}$ antagonist SCH $23390(30 \mu \mathrm{g} / \mathrm{kg}$ ) was administered to wild-type mice either in saline ( - or 0$)$ or in combination with a $\beta$-adrenergic receptor antagonist. $\boldsymbol{F}$, The $\beta$ antagonists used were either the nonselective $\beta$ blocker (-)-propranolol $(\beta)$, the $\beta_{1}$-selective blocker CGP 20712A $\left(\beta_{1}\right)$, or the $\beta_{2}$-selective blocker ICl 118,551 ( $\left.\beta_{2}\right)$, each at $1 \mathrm{mg} / \mathrm{kg} . p=0.0005$ for the main effect of treatment (6-9/group). G, ICl tested at lower doses in combination with SCH (30 $\mu \mathrm{g} / \mathrm{kg}) . p=0.003$ for the main effect of dose (6-12/group). $\boldsymbol{H}, \mathrm{SCH}(30 \mu \mathrm{g} / \mathrm{kg})$ was administered with the $\beta_{2}$ agonist procaterol. $p=0.0008$ for the main effect of dose (6/group). ${ }^{*} p<0.05,{ }^{\wedge} p<0.01,{ }^{\#} p<0.001$.

dopamine $\beta$-hydroxylase gene ( $D b h^{-/-}$) (Thomas et al., 1995). The same general treatment protocol was used for this and subsequent experiments (Fig. $1 A$ ). One day after fear conditioning, $D b h^{-1-}$ mice treated immediately after training with the $\mathrm{D}_{1,5}$ antagonist $\mathrm{SCH}$ at $10-30 \mu \mathrm{g} / \mathrm{kg}$ body weight exhibited low freezing in response to the training cue (a tone that immediately preceded shock) compared with $\mathrm{Dbh}^{-1-}$ mice treated with vehicle or with wild-type mice treated with either $\mathrm{SCH}$ or vehicle (Fig. $1 B$ ).

In a separate group of mice tested for their contextual fear of the training apparatus (no tone), SCH also impaired consolidation selectively in $\mathrm{Dbh} \mathrm{h}^{-1-}$ mice relative to wild-type mice (Fig. $1 C)$. Mice lacking NE/E exhibit impaired retrieval of contextual fear $1 \mathrm{~d}$ after conditioning due to lack of $\beta_{1}$ signaling (Murchison et al., 2004). Thus, to examine potential effects of NE/E deficiency on consolidation, retrieval was rescued in the contextual fear experiment by administering the $\beta_{1}$-selective agonist xamoterol shortly before testing (Hicks et al., 1987; Murchison et al., 2004). For simplicity, subsequent experiments using classical fear conditioning focused on cued fear, for which retrieval is independent of NE/E.

In addition to classical fear, we examined whether consolidation of instrumental fear requires $\mathrm{NE} / \mathrm{E}$ and/or $\mathrm{D}_{1,5}$ signaling. Wild-type and $\mathrm{Dbh}^{-1-}$ mice were treated with either vehicle or $\mathrm{SCH}$ immediately after conditioning. Neither the absence of $\mathrm{NE} / \mathrm{E}$ by itself nor treatment of wild-type mice with $\mathrm{SCH}$ impaired consolidation of instrumental fear (Fig. $1 D$ ), confirming previous observations with $\mathrm{Dbh}{ }^{-1-}$ mice (Thomas and Palmiter, 1997). Furthermore, and in contrast to the results for classical fear, treatment of $\mathrm{Dbh}^{-1-}$ mice with SCH also had no effect on the consolidation of instrumental fear. Differences in signaling mechanisms between instrumental and classical fear conditioning may parallel differences in their reliance on the amygdala (Wilensky et al., 2000).
A potential confound of the above results for classical fear conditioning is that $\mathrm{SCH}$ is also an agonist at serotonin $5-\mathrm{HT}_{2 \mathrm{C}}$ receptors (Ramos et al., 2005). To further examine a role for $D_{1,5}$ receptors, we used a less potent but more selective $D_{1,5}$ antagonist, ecopipam, that lacks serotonin receptor activity (Chipkin et al., 1988). Similar to SCH, ecopipam impaired cued fear memory consolidation selectively in $\mathrm{Dbh} \mathrm{h}^{-1-}$ mice (Fig. $1 \mathrm{E}$ ).

The results to this point are consistent with two distinct potential roles for DA in classical fear memory consolidation. First, DA might not normally play a role in consolidation, but instead might compensate for the chronic lack of NE/E in $\mathrm{Dbh}{ }^{-/-}$mice. Alternatively, NE/E and DA might both contribute to consolidation, but their roles would be redundant. In the latter case, stimulation of either system might facilitate consolidation, but only impairments in signaling by both systems would cause deficits in consolidation. To evaluate these possibilities, wild-type mice were treated with $\mathrm{SCH}$, the $\beta$-adrenergic receptor antagonist propranolol, or the combination. Mice treated with SCH or propranolol alone exhibited normal cued fear memory, while mice treated with the combination of SCH plus propranolol exhibited impaired memory (Fig. $1 F$ ). Furthermore, a selective $\beta_{2}$ antagonist (ICI $118,551=$ ICI) but not a selective $\beta_{1}$ antagonist (CGP 20712A) impaired consolidation when combined with $\mathrm{SCH}$, while ICI alone had no effect (O'Donnell and Wanstall, 1980; Dooley et al., 1986). Dose-response data indicated that ICI was fully effective at $30 \mu \mathrm{g} / \mathrm{kg}$ when it was combined with SCH (Fig. $1 G)$. The results provide strong initial support for the idea that $\mathrm{DA}$ and NE/E act in a redundant manner to consolidate classical fear memory.

Results from the antagonist studies suggest that $\beta_{2}$ signaling is required for the role of $\mathrm{NE} / \mathrm{E}$ in consolidation. To determine whether $\beta_{2}$ signaling is sufficient for the role of NE/E, $D b h^{-1-}$ mice were treated with both SCH (to impair consolidation) and various doses of the selective $\beta_{2}$ agonist procaterol (Waelbroeck 


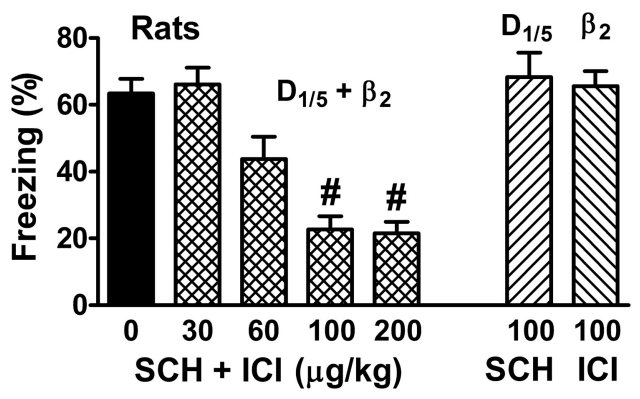

Figure 2. Redundancy for fear memory consolidation also occurs in rats. Experimental design was as depicted in Figure $1 A$ using intense shock (1.7 mA for rats). Rats were treated with either saline (0), $\mathrm{SCH}, \mathrm{ICl}$ or the combination. $p<0.0001$ for the main effect of treatment (4-8/group). ${ }^{\#} p<0.001$.

et al., 1983). Procaterol provided a dose-dependent rescue of cued fear memory consolidation, suggesting that $\beta_{2}$ signaling is sufficient for mediating the role of NE/E in consolidation in the absence of $\mathrm{D}_{1,5}$ signaling (Fig. $1 \mathrm{H}$ ).

\section{Redundancy also occurs in rats, is localized to the BLA, and is mediated by $D_{5}$ receptors}

Many prior studies examining the roles of catecholamines in fear memory have used rats rather than mice. To determine whether redundancy between catecholamines generalizes across species, rats were fear conditioned and treated with $\mathrm{SCH}$ and/or ICI. Consistent with the results obtained from mice, only concurrent administration of SCH and ICI impaired cued fear memory consolidation in rats (Fig. 2).

Because the BLA is critical for fear memory consolidation, we asked whether redundant catecholamine signaling occurs in this brain region. One week before conditioning, mice were cannulated to permit infusions into the BLA. When SCH and/or ICI were infused bilaterally immediately after training, only the combination of drugs impaired memory consolidation (Fig. 3A). To determine whether drug infusions into the BLA impair consolidation by affecting adjacent brain regions instead of the BLA, the SCH/ICI combination was infused into each of six locations surrounding the BLA (Fig. 3C). These infusions did not impair consolidation, indicating that the BLA is the site of drug action (Fig. $3 B$ ).

To genetically test a role for $\beta$ receptors, mice with a targeted disruption of the gene for either the $\beta_{1}$ - or $\beta_{2}$-adrenergic receptor were treated with SCH or vehicle. While SCH had no effect on consolidation in $\beta_{1}$ knock-out (KO) mice (Fig. $4 A$ ), SCH impaired consolidation in $\beta_{2} \mathrm{KO}$ mice (Fig. $4 B$ ). As a genetic complement to nonselective $\beta$ receptor blockade, cued fear memory was also examined in $\beta_{1,2}$ double $\mathrm{KO}$ mice, and no deficit was observed (Fig. 4C). Importantly, the pharmacologic studies to this point were unable to distinguish between the potential roles of $D_{1}$ and $D_{5}$ receptors in consolidation due to a lack of receptor subtype selectivity of the drugs. For this purpose, gene-targeted mice were used. While the $\beta_{2}$ antagonist ICI had no effect on consolidation in $\mathrm{D}_{1} \mathrm{KO}$ mice (Fig. $4 \mathrm{D}$ ), ICI impaired consolidation in $\mathrm{D}_{5} \mathrm{KO}$ mice (Fig. $4 E$ ), indicating that the role of DA in consolidation is mediated by the $\mathrm{D}_{5}$ receptor.

\section{Agonists of $\boldsymbol{\beta}_{2}$ or $\mathrm{D}_{5}$ receptors enhance fear memory consolidation}

Given the roles for $\beta_{2}$ and $D_{5}$ receptors defined above, we asked whether activating these specific receptors shortly after conditioning would enhance fear memory consolidation in mice when trained with a lower shock intensity. For NE/E, enhancement of consolidation by $\beta$ receptor stimulation has not been demonstrated for classical fear, although this has been demonstrated for instrumental fear (McGaugh and Roozendaal, 2002). For DA, results from BLA infusion of $\mathrm{a}_{1,5}$ receptor agonist before classical fear conditioning suggest that stimulation of these receptors enhances either acquisition or consolidation (Guarraci et al., 1999).

When wild-type mice were systemically injected with the $\beta_{2}$ agonist procaterol immediately after conditioning, cued fear memory was significantly enhanced (Fig. $5 A$ ). When mice were injected with the $\mathrm{D}_{1,5}$ agonist SKF 38393 immediately after conditioning, cued fear memory was also significantly enhanced (Fig. $5 B$ ). Of note, $D_{1,5}$ receptors can activate various downstream effectors, including $\mathrm{AC}$ and PLC, and certain $\mathrm{D}_{1,5}$ agonists can induce the selective activation of either AC or PLC (Undie et al., 1994; Jin et al., 2003). To gain insight into the initial mechanism by which $D_{1,5}$ receptors might enhance consolidation, effectorselective $D_{1,5}$ agonists were used. While an AC-selective $D_{1,5}$ agonist did not significantly alter consolidation, a PLC-selective $D_{1,5}$ agonist enhanced consolidation to an extent similar to that for the nonselective $\mathrm{D}_{1,5}$ agonist used initially (Fig. $5 B-D$ ). Because $D_{1,5}$ agonists do not distinguish between these two receptors, receptor $\mathrm{KO}$ and wild-type littermate control mice were used. The ability of the nonselective and PLC-selective $\mathrm{D}_{1,5}$ agonists to enhance consolidation was absent in $\mathrm{D}_{5} \mathrm{KO}$ mice, although the $\beta_{2}$ agonist procaterol remained effective (Fig. $5 E$ ). Similarly, the ability of procaterol to enhance consolidation was absent in $\beta_{2} \mathrm{KO}$ mice, although a $\mathrm{D}_{1,5}$ agonist remained effective (Fig. $5 F$ ).

\section{$\boldsymbol{\beta}_{2}$ and $\mathrm{D}_{5}$ signaling in consolidation converge on the activation of PLC}

Given that $\mathrm{D}_{5}$ may activate PLC to enhance fear memory consolidation, we asked whether directly stimulating PLC activity with the agonist m-3M3FBS enhances consolidation (Bae et al., 2003). In support of a role for PLC, infusion into the BLA of this PLC agonist also enhanced consolidation (Fig. 6A). We next asked whether inhibiting PLC activity would impair consolidation by infusing the PLC inhibitor edelfosine into the BLA immediately after training (Powis et al., 1992). Edelfosine dose-dependently impaired consolidation (Fig. 6B), suggesting that activation of PLC may be required for fear memory consolidation, and that this could be a site of convergence for $\mathrm{D}_{5}$ and $\beta_{2}$ signaling. Infusion of edelfosine either $1 \mathrm{~d}$ before or $4 \mathrm{~h}$ after conditioning had no effect on cued fear memory, indicating that edelfosine does not lesion the BLA or impair expression (Fig. 6C). Although prior studies support the possibility that $\mathrm{D}_{5}$ may signal via $\mathrm{G}_{\mathrm{q}}$ and $\mathrm{PLC}$ in the amygdala (Friedman et al., 1997; Leonard et al., 2003; Sahu et al., 2009), the only data indicating that $\beta_{2}$ could signal via PLC come from heterologous expression of $\beta_{2}$ receptors in HEK-293 cells in vitro (Keiper et al., 2004).

To determine whether $D_{5}, \beta_{2}$, or both receptors might signal via PLC to promote consolidation, we used edelfosine in two complementary experiments. The first experiment was based on the idea that PLC activity could be reduced to a point where it becomes rate-limiting for consolidation. To achieve this, edelfosine was infused into the BLA at the highest dose $(0.2 \mathrm{ng})$ that did not impair consolidation. We then examined the combinatorial effects of PLC and receptor blockade. Edelfosine at $0.2 \mathrm{ng}$ was administered with a dose (50 ng) of either SCH or ICI that impairs consolidation when combined with each other but not when given alone (Fig. $3 A$ ). The combination of edelfosine plus 

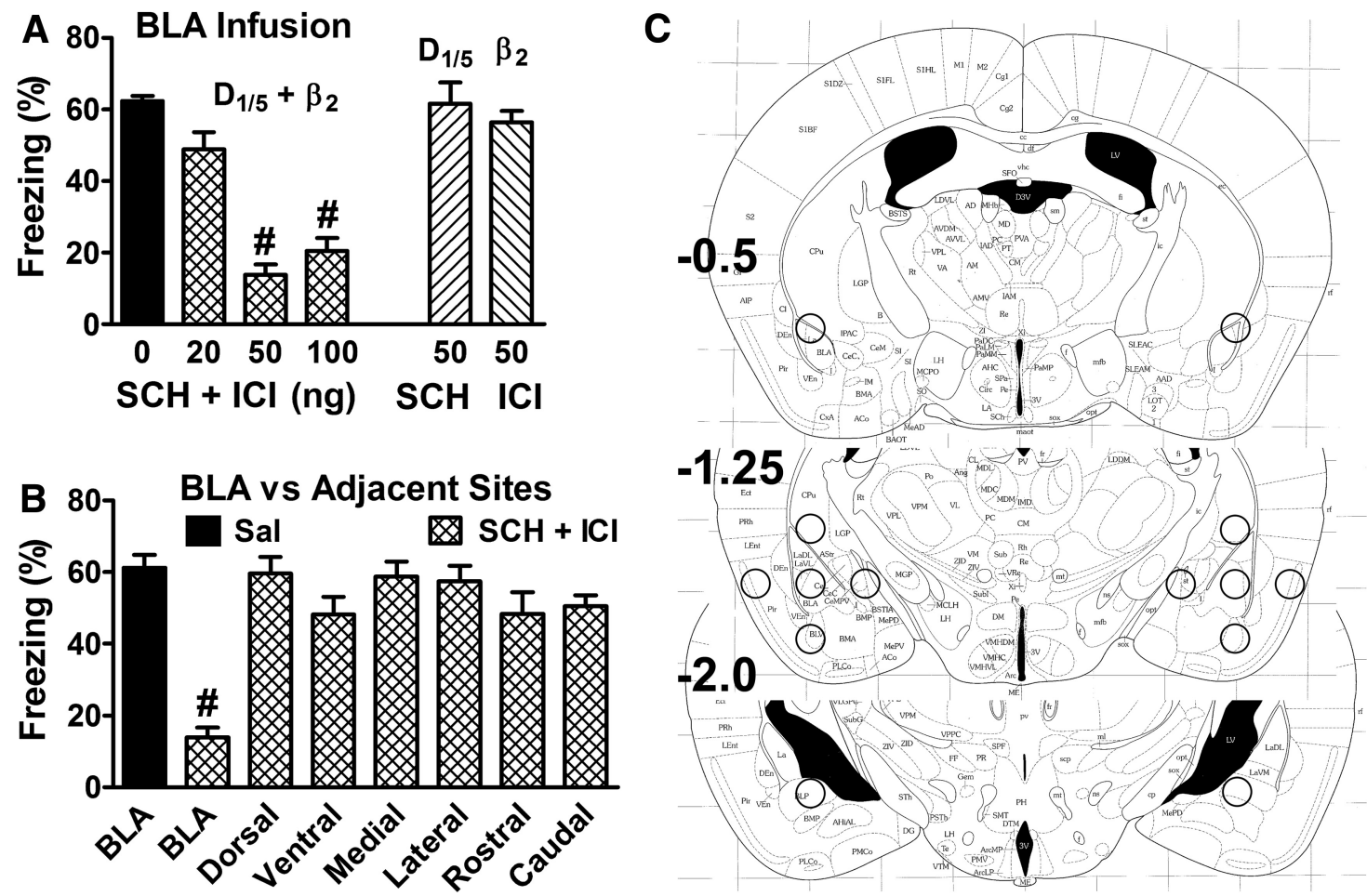

Figure 3. BLA is the locus of redundant signaling in fear memory consolidation. Experimental design was as depicted in Figure $1 A$ using intense shock ( $1 \mathrm{~mA}$ for mice). $A$, Drugs were infused bilaterally into the BLA of wild-type mice. $p<0.0001$ for the main effect of treatment (5-8/group). $B$, The combination of SCH plus ICI (each $50 \mathrm{ng}$ ) was infused bilaterally into the BLA or into adjacent brain regions displaced $0.75 \mathrm{~mm}$ in the direction indicated. $p<0.0001$ for the main effect of treatment (5-6/group). C, Injection cannula tips were located within spheres marked by the circles on the atlas drawings (Frankland and Paxinos, 1997). ${ }^{\#} p<0.001$.
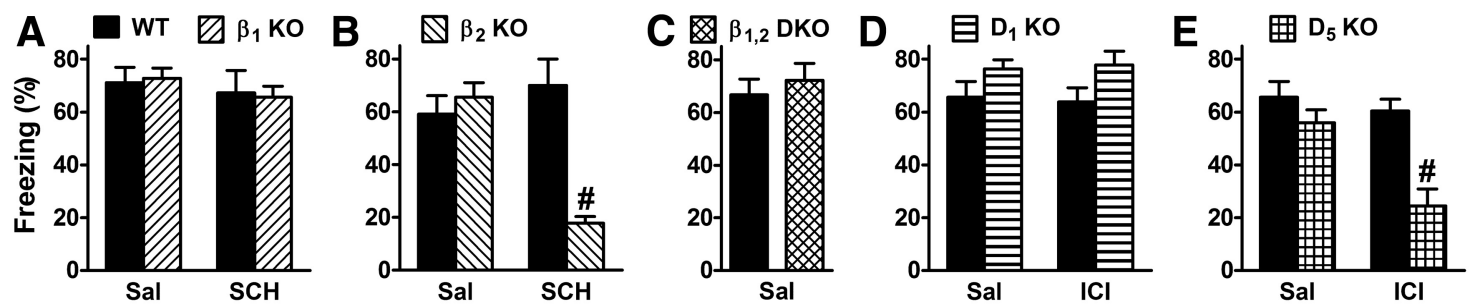

Figure 4. The role of $\mathrm{DA}$ in fear memory consolidation is mediated by $\mathrm{D}_{5}$ receptors. Experimental design was as depicted in Figure $1 A$ using intense shock $(1 \mathrm{~mA})$. $A, B$, Either saline $(S a l)$ or a $\mathrm{D}_{1 / 5}$ antagonist ( $\mathrm{SCH}, 30 \mu \mathrm{g} / \mathrm{kg}$ ) was administered to wild-type (WT) and $\beta$ receptor knock-out (K0) mice. For $\beta_{2}$ mice, $p=0.016$ for the main effect of treatment; $p=0.0044$ for the main effect of genotype; and $p=0.0006$ for the interaction of treatment and genotype (5/group). C, Sal was administered to WT and $\beta_{1,2}$ double K0 mice. No significant difference was observed (5/group). $\boldsymbol{D}$, $E$, Either Sal or a $\beta_{2}$ antagonist $\left(\mathrm{ICl}, 30 \mu \mathrm{g} / \mathrm{kg}\right.$ ) was administered to WT and DA receptor K0 mice. For $D_{5}$ mice, $p=0.004$ for the main effect of treatment; $p=0.0006$ for the main effect of genotype; and $p=0.029$ for the interaction of treatment and genotype (5-8/group). ${ }^{*} p<0.001$.

SCH and the combination of edelfosine plus ICI each impaired consolidation (Fig. 6B).

The second experiment examined the ability of agonists to enhance consolidation when PLC was inhibited. Edelfosine, at the smallest dose ( $2 \mathrm{ng})$ that impaired consolidation of highshock intensity training, was infused into the BLA while administering a $D_{1,5}$ or $\beta_{2}$ agonist systemically immediately after training with lower shock intensity. Edelfosine blocked the enhancements of consolidation induced by the $\mathrm{D}_{1,5}$ agonist and by the $\beta_{2}$ agonist (Fig. 6D).

Results from the above two experiments suggested that $D_{5}$ and $\beta_{2}$ receptors may both signal via PLC to promote consolidation. To further test this possibility, inositol-1,4,5-trisphosphate ( $\left.\mathrm{IP}_{3}\right)$, a second messenger molecule generated by PLC activity, was measured in the BLA following systemic administration of a $D_{1,5}$ or $\beta_{2}$ agonist. Significant increases in $\mathrm{IP}_{3}$ levels in the BLA were observed ex vivo with each agonist in wild-type mice (Fig. 7A).
Because this is a novel finding for $\beta_{2}$ stimulation, $\beta_{2} \mathrm{KO}$ mice were also examined. In these mice, a $D_{1,5}$ agonist but not a $\beta_{2}$ agonist caused BLA IP ${ }_{3}$ levels to increase (Fig. $7 B$ ). For $\mathrm{D}_{5}$, others have shown that the ability of $\mathrm{D}_{1,5}$ agonists to augment $\mathrm{IP}_{3}$ levels in various brain regions is absent in $\mathrm{D}_{5} \mathrm{KO}$ mice (Sahu et al., 2009).

Finally, we asked whether learning-specific activation of PLC occurs in the BLA by measuring IP ${ }_{3}$ levels ex vivo following fear conditioning. $\mathrm{IP}_{3}$ levels were elevated in the BLA 30 min after fear conditioning when compared with pseudoconditioning or no conditioning (Fig. 7C). The elevation in $\mathrm{IP}_{3}$ was selective for this time point, as several earlier and later time points from 3-60 min did not show elevation (Fig. 7D). Systemic administration of $\mathrm{SCH}$ or ICI immediately after conditioning had no effect on $\mathrm{IP}_{3}$ levels $30 \mathrm{~min}$ after conditioning (Fig. 7E). In contrast, administration of SCH and ICI combined significantly reduced $\mathrm{IP}_{3}$ levels relative to vehicle administration, demonstrat- 

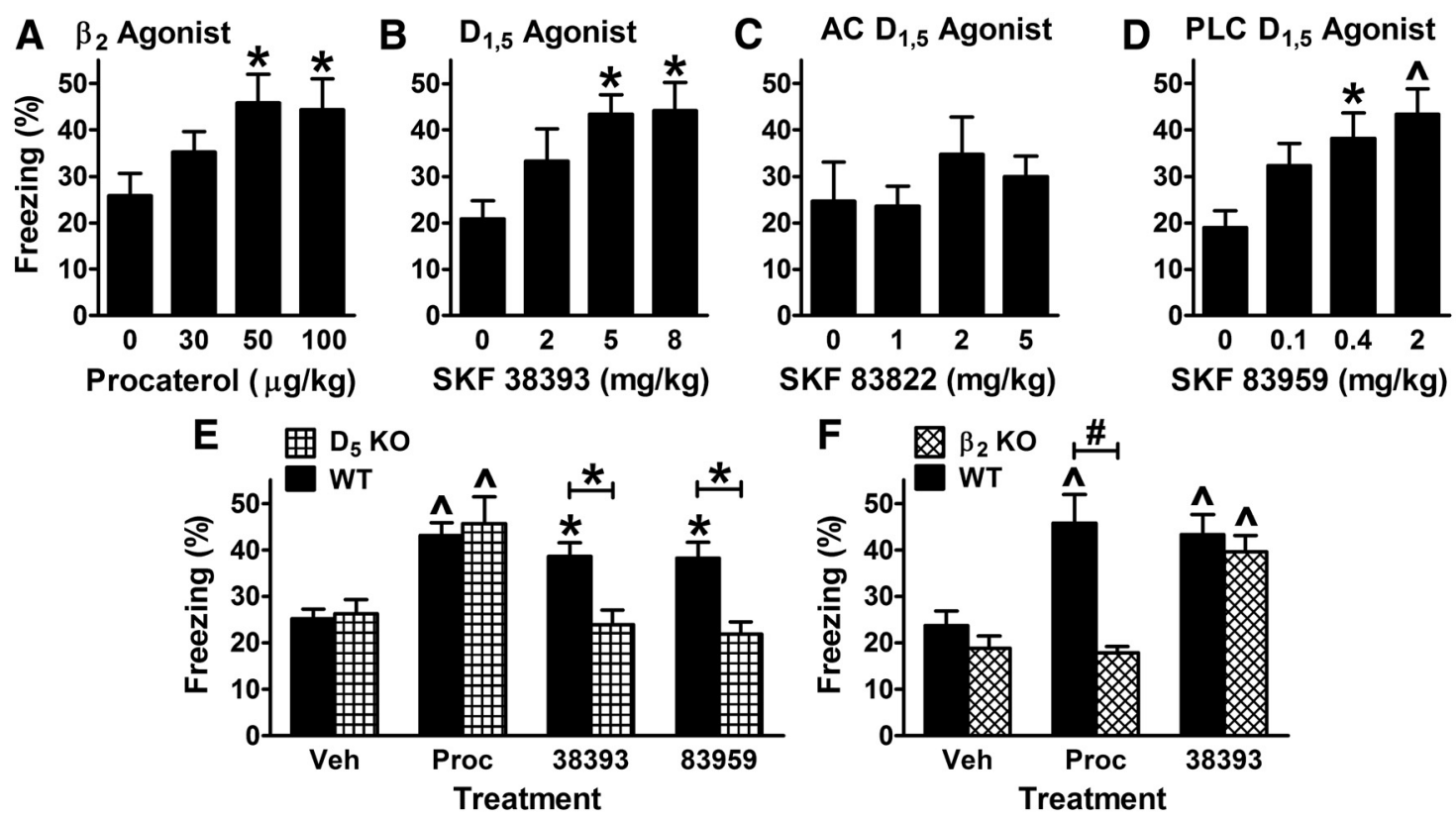

Figure 5. Agonists of $\beta_{2}$ or $D_{5}$ receptors enhance fear memory consolidation. Experimental design was as depicted in Figure $1 A$ using moderate shock $(0.4 \mathrm{~mA})$. $A$, Various doses of the $\beta_{2}$ agonist procaterol were injected immediately after conditioning. $p=0.043$ for the main effect of dose (6-11/group). $\boldsymbol{B}-\boldsymbol{D}$, Various doses of either a nonselective $D_{1 / 5}$ agonist (SKF 38393), a $\mathrm{D}_{1 / 5}$ agonist that selectively activates AC (SKF 83822), or a $\mathrm{D}_{1 / 5}$ agonist that selectively activates PLC (SKF 83959) were tested. $p=0.017$ and $p=0.0038$ for the main effect of dose for SKF 38393 and SKF 83959 , respectively (8-13/group). $E$, F, Procaterol ( $50 \mu \mathrm{g} / \mathrm{kg}$ ) or $D_{1 / 5}$ agonist (5 mg/kg for SKF 38393 or $2 \mathrm{mg} / \mathrm{kg}$ for SKF 83959$)$ was administered to $\beta_{2}$ $\mathrm{K} 0$ and $\mathrm{D}_{5} \mathrm{KO}$ mice and their wild-type littermate controls. $E, p=0.0001$ for the main effect of treatment; $p=0.013$ for the main effect of genotype; and $p=0.015$ for the interaction of treatment and genotype (8-31/group). $\boldsymbol{F}, p<0.0001$ for the main effect of treatment; $p=0.0009$ for the main effect of genotype; and $p=0.009$ for the interaction of treatment and genotype (5-13/group). ${ }^{*} p<0.05,{ }^{\wedge} p<0.01,{ }^{\#} p<0.001$.
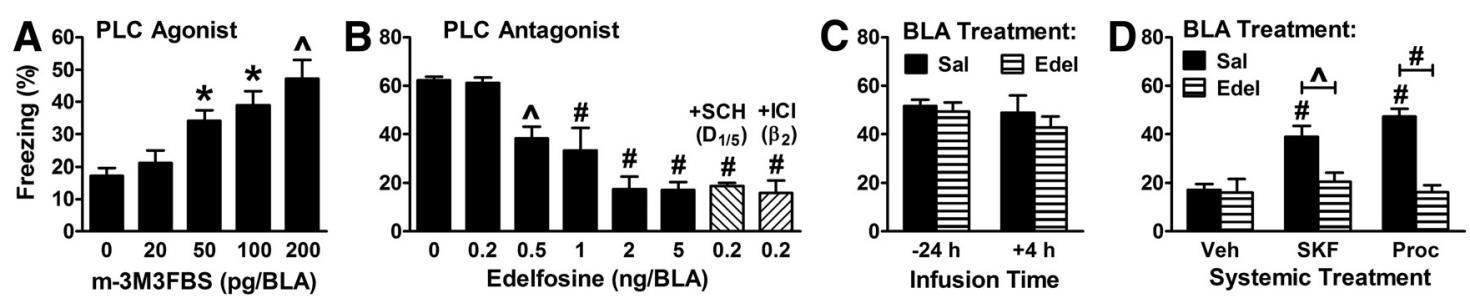

Figure 6. PLC is a critical regulator of consolidation. Experimental design was similar to that depicted in Figure $1 A$ using moderate or intense shock $(0.4$ or $1 \mathrm{~mA}) . \boldsymbol{A}$, The PLC agonist $\mathrm{m}-3 \mathrm{M} 3 \mathrm{FBS}$ was infused into the BLA of wild-type mice after training with $0.4 \mathrm{~mA} . p=0.001$ for the main effect of dose (5/group). $B$, The PLC inhibitor edelfosine alone or in combination with either ICI $(50 \mathrm{ng})$ or SCH $(50 \mathrm{ng})$ was infused into the BLA after training with $1 \mathrm{~mA} . p<0.0001$ for the main effect of treatment (5-7/group). C, Infusion time is relative to conditioning. Cued fear testing was performed $1 \mathrm{~d}$ after training. The main effects of treatment and of time, as well as their interaction, were not significant (5/group). $\boldsymbol{D}$, Mice were fear conditioned using $0.4 \mathrm{~mA}$. Saline (Sal) or edelfosine $(2 \mathrm{ng})$ was then infused into the BLA, and immediately afterward either vehicle, $S K F \quad 83959(2 \mathrm{mg} / \mathrm{kg})$ or procaterol $(50 \mathrm{ng} / \mathrm{kg})$ was injected intraperitoneally. $p=0.001$ for the main effect of agonist; $p<0.0001$ for the main effect of antagonist; and $p=0.0027$ for the interaction of agonist and antagonist ( $5 /$ group). ${ }^{*} p<0.05,{ }^{p} p<0.01,{ }^{\#} p<0.001$.
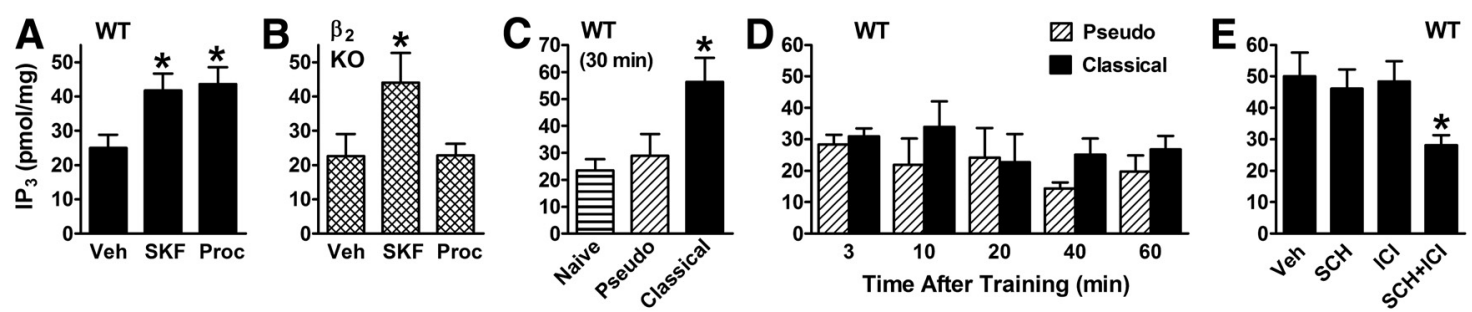

Figure 7. Redundancy between $\beta_{2}$ and $D_{5}$ signaling occurs via activation of PLC. Experimental design was similar to that depicted in Figure $1 A$ using moderate or intense shock $(0.4$ or $1 \mathrm{~mA})$. $A$, Wild-type mice were injected intraperitoneally with either vehicle, SKF $83959\left(2 \mathrm{mg} / \mathrm{kg}\right.$ ) or procaterol $\left(50 \mathrm{ng} / \mathrm{kg}\right.$ ) and killed $30 \mathrm{~min}$ later. Punches from the BLA were assayed for $I \mathrm{P}_{3}(\mathrm{pmol} / \mathrm{mg}$ protein). $p=0.045$ for the main effect of agonist (10/group). $\boldsymbol{B}, \beta_{2}$ KO mice were treated as described in $\boldsymbol{A}$. $p=0.044$ for the main effect of agonist ( $9-10 /$ group). $\boldsymbol{C}$, Mice were treated as indicated and killed $30 \mathrm{~min}$ later. Shock intensity was $1 \mathrm{~mA}$ for the pseudo- and classical-conditioned groups. The classical-conditioned group exhibited significantly higher $\mathrm{IP}_{3}$ levels in the BLA relative to the pseudo-conditioned ( $p=0.033$ ) and naive ( $p=0.016$ ) groups. $p=0.021$ for the main effect of conditioning $(6-10 /$ group). $\boldsymbol{D}$, Mice were handled as in $(\boldsymbol{C})$ and killed at the times indicated. Main effects and their interaction were not significant (5-7/group). E, Mice were fear conditioned using $1 \mathrm{~mA}$ and then injected intraperitoneally with either Sal, SCH (30 $\mu \mathrm{g} / \mathrm{kg}), \mathrm{ICI}(30 \mu \mathrm{g} / \mathrm{kg})$, or the combination of $\mathrm{SCH}$ and ICl, and killed 30 min later. Only combined treatment caused a significant reduction in conditioning-induced $\mathrm{IP}_{3}$ levels in the BLA. $p=0.039 \mathrm{for}$ the main effect of treatment (21/group). ${ }^{*} p<0.05$. 
ing that redundancy in receptor function extends to the learning-induced production of $\mathrm{IP}_{3}$ in the BLA.

\section{$\boldsymbol{\beta}_{2}$ activation of PLC in the BLA is mediated by $\mathrm{G}_{\mathrm{i} / \mathrm{o}}$}

While there is considerable evidence indicating that $D_{5}$ couples to $G_{q}$ to activate PLC, evidence for the coupling of $\beta_{2}$ to $G_{4}$ is lacking. A study in HEK-293 cells suggested that by coupling to $G_{s}, \beta_{2}$ receptors can sequentially activate AC, Epac, Rap2, and PLC $\varepsilon$. However, recent results from our laboratory suggested an alternate potential mechanism for coupling $\beta_{2}$ to PLC in the brain. Retrieval of contextual fear memory requires $\mathrm{NE}, \beta_{1}, \mathrm{G}_{\mathrm{s}}$, and $\mathrm{AC}$ signaling in the hippocampus (Ouyang et al., 2008). $\beta_{2}$ signaling impairs retrieval by stimulating the inhibitory $G_{i}$ class of $G$ proteins, causing cAMP levels to decrease in the hippocampus (Schutsky et al., 2011). Of potential relevance, $G_{i}$ signaling can also result in the activation of PLC by releasing $\beta \gamma$ subunits that are capable of stimulating PLC $\beta$ isoforms. Therefore, we asked whether such a mechanism might apply to $\beta_{2}$ signaling in the BLA for consolidation.

Pertussis toxin (PTx) inactivates $G_{i / o}$ proteins through ADP ribosylation, uncoupling them from their receptors. Because it takes several days to observe optimal efficacy when PTx is administered in vivo, PTx was infused into the BLA 3 d before conditioning (Goh and Pennefather, 1989; Stratton et al., 1989). BLA pretreatment with PTx had no effect on consolidation when saline was infused immediately after training, suggesting that $\mathrm{G}_{\mathrm{i} / \mathrm{o}}$ signaling is not essential for consolidation (Fig. 8A). That outcome was expected if only one of the redundant pathways uses $\mathrm{G}_{\mathrm{i} / \mathrm{o}}$. Interestingly, pretreatment with PTx impaired consolidation when SCH was infused immediately after training. This outcome suggested that PTx pretreatment might be mimicking $\beta_{2}$ blockade. In support of this idea, pretreatment with PTx did not affect consolidation when ICI was infused immediately after training. Together, these results suggest that $\beta_{2}$ but not $D_{5}$ signaling in the BLA is mediated by $\mathrm{G}_{\mathrm{i} / \mathrm{o}}$. To further test this possibility, PTx was infused into the BLA before treating with receptor agonists to enhance consolidation. PTx pretreatment blocked the enhancement of consolidation normally observed following systemic treatment with a $\beta_{2}$ agonist, but had no effect on the ability of a $D_{1,5}$ agonist to enhance consolidation (Fig. $8 B$ ).

\section{Discussion}

In summary, our experiments identify an important but redundant role in classical fear memory consolidation for adrenergic signaling by $\beta_{2}$ receptors and dopaminergic signaling by $\mathrm{D}_{5}$ receptors (Fig. 9). It is well recognized that there are multiple stressresponse mediators with distinct but overlapping temporal and $0.05 ;{ }^{\wedge} p<0.01,{ }^{\#} p<0.001$.
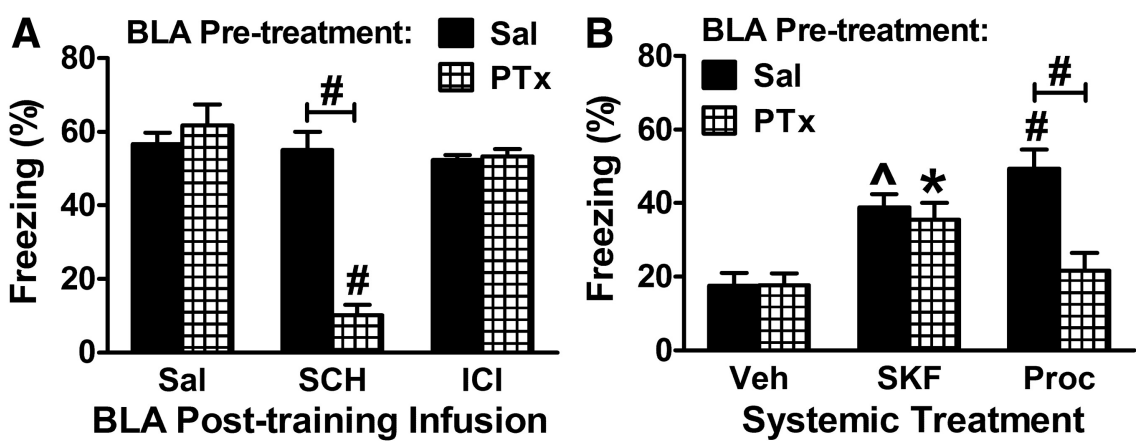

Figure 8. $\quad \beta_{2}$ activation of $\mathrm{PLC}$ in the $\mathrm{BLA}$ is mediated by $\mathrm{G}_{\mathrm{i} / 0}$. Experimental design was similar to that depicted in Figure $1 \mathrm{~A}$ using moderate or intense shock (0.4 or $1 \mathrm{~mA}$ ). A, Pertussis toxin (PTx, $1 \mathrm{ng}$ ) or Sal was infused into the BLA $3 \mathrm{~d}$ before training. Immediately after training with $1 \mathrm{~mA}$, either Sal, SCH $(50 \mathrm{ng})$, or ICl ( $50 \mathrm{ng}$ ) was infused into the BLA. $p=0.0002$ for the main effect of pretreatment; $p<0.0001$ for the main effect of treatment; and $p<0.0001$ for the interaction of pretreatment and treatment $83959(2 \mathrm{mg} / \mathrm{kg})$, or procaterol $(50 \mu \mathrm{g} / \mathrm{kg})$ was injected intraperitoneally. $p=0.018$ for the main effect of pretreatment; $p=$ 0.0009 for the main effect of treatment; and $p=0.014$ for the interaction of pretreatment and treatment $\left(5-10 /\right.$ group). ${ }^{*} p<$

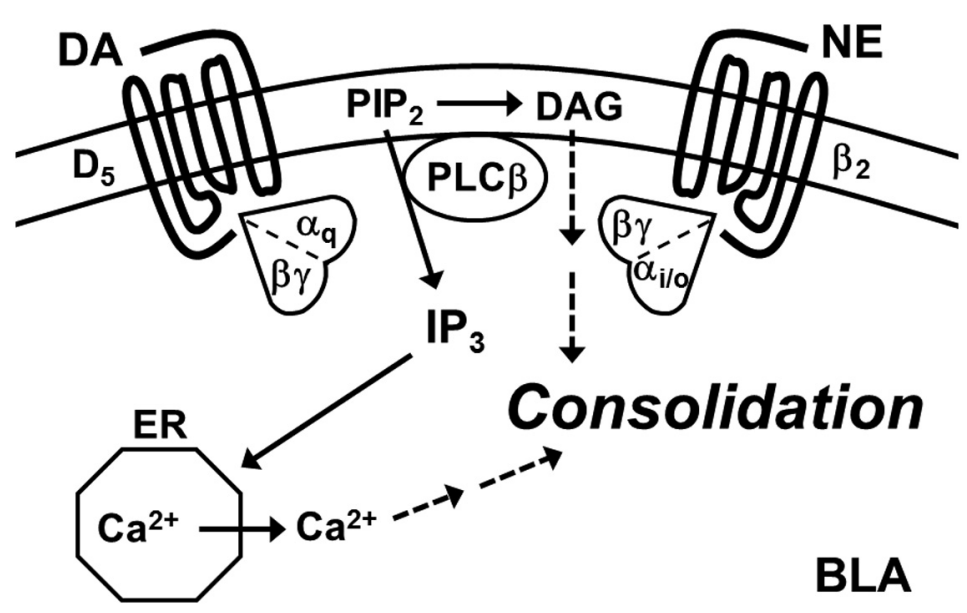

Figure 9. Schematic diagram of functional redundancy. DA and NE are functionally redundant for fear memory consolidation in the $\mathrm{BLA}$ due to activation of $\mathrm{PLC}$ by $\mathrm{D}_{5}-\mathrm{G}_{\mathrm{q}} \alpha$ and $\beta_{2}-\mathrm{G}_{\mathrm{i} / \mathrm{o}} \beta \gamma$ receptor signaling. Whether downstream signaling activated by the vating a conventional isozyme of protein kinase ( that is implicated in fear memory consolidation (Weeber et al., 2000). The cell type(s) in which this signaling occurs has yet to be defined. Phosphatidylinositol 4,5-bisphosphate ( $\mathrm{PIP}_{2}$ ) is a substrate of PLC. The endoplasmic reticulum (ER) stores $\mathrm{Ca}^{2+}$ for cytosolic release that is induced by $\mathrm{IP}_{3}$.

mechanistic attributes (Joëls and Baram, 2009). Redundancy in systems responsible for potentially life-preserving processes such as long-term fear memory consolidation could be advantageous for survival. While we have found that NE and DA act in a redundant manner to consolidate classical fear memory, it is also possible that each has additional unique roles during (but not essential to) consolidation that may be identified in future studies.

While it has been widely hypothesized that endogenous NE/E and $\beta$-adrenergic signaling play critical roles in amygdaladependent emotional memory consolidation, there is a paucity of evidence indicating that such signaling is uniquely required for this. In one study suggesting a unique role, various $\beta$ receptor antagonists (including ICI) were infused into the BLA of rats immediately after cued fear conditioning, and impairment of cued fear was reported $1 \mathrm{~d}$ later ( $\mathrm{Qu}$ et al., 2008). However, the doses of antagonist used were 100-fold higher than those found to be effective for ICI (when combined with SCH) in the current 
study, and are considerably higher than what should be necessary for the size difference between rats and mice. Another study suggested that $\beta$ receptors contribute to the acquisition but not consolidation of cued fear memory (Bush et al., 2010). However, it is difficult to reconcile the above observations with results from mouse genetic models, which do not support a unique role for $\beta$ receptors in the acquisition, consolidation, or retrieval of cued fear memory: $D b h^{-1-}, \beta_{1} \mathrm{KO}, \beta_{2} \mathrm{KO}$, or $\beta_{1} / \beta_{2}$ double $\mathrm{KO}$ mice do not exhibit cued fear deficits. Furthermore, our pharmacologic data from the current study and a previous study using mice and rats support the genetic findings (Murchison et al., 2004).

With respect to the role for DA, results from some studies suggest that $D_{1,5}$ signaling might be required for fear memory acquisition or consolidation (Guarraci et al., 1999; Greba and Kokkinidis, 2000). However, doses of SCH used in those studies (systemic or intra-BLA) were 10- to 100-fold higher than those found to be effective here, potentially lacking specificity for $D_{1,5}$ signaling. Relevant to this, we did not observe a fear conditioning deficit in $\mathrm{D}_{1}$ or $\mathrm{D}_{5} \mathrm{KO}$ mice, confirming previous results (ElGhundi et al., 1999; Holmes et al., 2001). These and our results contrast with a recent study reporting a deficit in either the acquisition or consolidation of fear-potentiated startle in $\mathrm{D}_{1} \mathrm{KO}$ mice (Fadok et al., 2009). In that study, conditioning used 30 trials reinforced by mild footshocks $(0.2 \mathrm{~mA}$ for $0.5 \mathrm{~s})$, while the current study examined the consolidation of more intense fear resulting from a single, strongly aversive footshock ( $1 \mathrm{~mA}$ for $2 \mathrm{~s}$ ). It is possible that the mechanisms underlying the consolidation of multiple weakly reinforced training trials are different from those for a single, strongly reinforced event.

Given that $\beta_{2}$ and $D_{5}$ receptors can couple to $G_{s}$, and that cAMP signaling is required for classical fear memory consolidation (Schafe and LeDoux, 2000), it is interesting that neither $\beta_{2}$ nor $\mathrm{D}_{5}$ signaling in the amygdala may increase cAMP levels. DA and $\mathrm{D}_{1,5}$ agonists fail to elevate cAMP in the BLA (Leonard et al., 2003), and stimulation of $\beta_{2}$ receptors in hippocampal slices causes a decrease in cAMP (Schutsky et al., 2011). However, our results are consistent with observations indicating that $\mathrm{D}_{1,5}$ agonists activate PLC rather than AC in the BLA, and that activation of PLC by DA is greatly diminished in $\mathrm{D}_{5}$ but not $\mathrm{D}_{1} \mathrm{KO}$ mice (Friedman et al., 1997; Leonard et al., 2003; Sahu et al., 2009). Our results are also consistent with observations indicating that signaling by $\beta_{2}$ receptors in the heart and hippocampus depends predominantly on $\mathrm{G}_{\mathrm{i} / \mathrm{o}}$ rather than $\mathrm{G}_{\mathrm{s}}$ (Rockman et al., 2002; Schutsky et al., 2011).

Results from the current study indicate that $\beta_{2}$ and $D_{5}$ receptor signaling converge and become redundant by activating PLC. Remarkably, there is little evidence that canonical neurotransmitter signaling pathways that activate $\mathrm{G}_{\mathrm{q}} / \mathrm{PLC}$ are required for fear memory. Gene-targeted mice lacking expression of either metabotropic glutamate receptor mGluR1 or mGluR5, muscarinic acetylcholine receptor $\mathrm{M}_{1}$ or $\mathrm{M}_{3}$, serotonergic receptor $5-\mathrm{HT}_{2 \mathrm{a}}$ or $5-\mathrm{HT}_{2 \mathrm{c}}$, adrenergic receptor $\alpha_{1 \mathrm{~d}}$, or histaminergic receptor $\mathrm{H}_{1}$ all exhibit intact cued fear memory (Aiba et al., 1994; Lu et al., 1997; Tecott et al., 1998; Anagnostaras et al., 2003; Sadalge et al., 2003; Weisstaub et al., 2006; Dai et al., 2007; Poulin et al., 2010). Pharmacologically, there is evidence for and against mGluR5 signaling being required for cued fear memory (Nielsen et al., 1997; Rodrigues et al., 2002; Gravius et al., 2006), although stimulating mGluR1/5 receptors can enhance fear memory (Rudy and Matus-Amat, 2009). For NE/E, antagonist treatment suggests that $\alpha_{1}$-adrenergic signaling is not required for fear memory (Lazzaro et al., 2010). On the other hand, mice with a targeted disruption of the gene for PLC- $\beta 1$ exhibit greatly re- duced contextual fear, although this could be due to a deficit in hippocampus-dependent memory rather than BLA-dependent fear memory per se (McOmish et al., 2008a,b).

Stimulation of PLC is likely to activate $\mathrm{Ca}^{2+}$ - and diacylglycerol-dependent signaling such as that mediated by protein kinase $\mathrm{C}$ (PKC) and calmodulin-dependent kinases (CaMKs). Genetic and pharmacologic data support a role for these kinases in fear memory. Genetic disruption of the PKC $\beta$ gene or the CaMKIV gene results in impaired cued and contextual fear (Weeber et al., 2000; Wei et al., 2002), and inhibitors of PKC infused into the BLA shortly after conditioning impairs consolidation of instrumental fear (Bonini et al., 2005). In addition to the generation of $\mathrm{IP}_{3}$, it will be valuable in future studies to identify the signaling events that are altered when $\beta_{2}$ and $D_{5}$ receptors are antagonized. It will also be valuable to determine in what cell type(s) these receptors act to promote consolidation, given that the potential expression and physiological effects of these receptors in the BLA are broad and diverse (Ciliax et al., 2000; Qu et al., 2008; Farb et al., 2010).

In humans, some studies indicate that blocking $\beta$ receptors eliminates enhanced memory for emotionally arousing items, although other studies have not corroborated these findings (Cahill et al., 1994; O'Carroll et al., 1999). If $\beta$ blockers have this effect, it would suggest a lack of redundancy under these conditions. This could be due to differences in arousal systems engaged by viewing aversive material versus experiencing a potentially life-threatening event, such as may occur with fear conditioning or events that can lead to the development of PTSD. Results from recent clinical trials suggest that $\beta$ blockers are of limited efficacy in the prevention of PTSD (Stein et al., 2007; McGhee et al., 2009; Nugent et al., 2010). Our results suggest that combined $D_{5} / \beta_{2}$ blockade might be more efficacious.

\section{References}

Aiba A, Chen C, Herrup K, Rosenmund C, Stevens CF, Tonegawa S (1994) Reduced hippocampal long-term potentiation and context-specific deficit in associative learning in mGluR1 mutant mice. Cell 79:365-375.

Anagnostaras SG, Murphy GG, Hamilton SE, Mitchell SL, Rahnama NP, Nathanson NM, Silva AJ (2003) Selective cognitive dysfunction in acetylcholine M1 muscarinic receptor mutant mice. Nat Neurosci 6:51-58.

Anstrom KK, Woodward DJ (2005) Restraint increases dopaminergic burst firing in awake rats. Neuropsychopharmacology 30:1832-1840.

Bae YS, Lee TG, Park JC, Hur JH, Kim Y, Heo K, Kwak JY, Suh PG, Ryu SH (2003) Identification of a compound that directly stimulates phospholipase C activity. Mol Pharmacol 63:1043-1050.

Bonini JS, Cammarota M, Kerr DS, Bevilaqua LR, Izquierdo I (2005) Inhibition of PKC in basolateral amygdala and posterior parietal cortex impairs consolidation of inhibitory avoidance memory. Pharmacol Biochem Behav 80:63-67.

Bush DE, Caparosa EM, Gekker A, LeDoux J (2010) Beta-adrenergic receptors in the lateral nucleus of the amygdala contribute to the acquisition but not the consolidation of auditory fear conditioning. Front Behav Neurosci 4:154.

Cahill L, Prins B, Weber M, McGaugh JL (1994) Beta-adrenergic activation and memory for emotional events. Nature 371:702-704.

Chipkin RE, Iorio LC, Coffin VL, McQuade RD, Berger JG, Barnett A (1988) Pharmacological profile of SCH39166: a dopamine D1 selective benzonaphthazepine with potential antipsychotic activity. J Pharmacol Exp Ther 247:1093-1102.

Chruscinski AJ, Rohrer DK, Schauble E, Desai KH, Bernstein D, Kobilka BK (1999) Targeted disruption of the beta2 adrenergic receptor gene. J Biol Chem 274:16694-16700.

Ciliax BJ, Nash N, Heilman C, Sunahara R, Hartney A, Tiberi M, Rye DB, Caron MG, Niznik HB, Levey AI (2000) Dopamine D(5) receptor immunolocalization in rat and monkey brain. Synapse 37:125-145.

Dai H, Kaneko K, Kato H, Fujii S, Jing Y, Xu A, Sakurai E, Kato M, Okamura N, Kuramasu A, Yanai K (2007) Selective cognitive dysfunction in mice lacking histamine $\mathrm{H} 1$ and $\mathrm{H} 2$ receptors. Neurosci Res 57:306-313. 
Debiec J, LeDoux JE (2004) Disruption of reconsolidation but not consolidation of auditory fear conditioning by noradrenergic blockade in the amygdala. Neuroscience 129:267-272.

Dooley DJ, Bittiger H, Reymann NC (1986) CGP 20712 A: a useful tool for quantitating beta 1- and beta 2- adrenoceptors. Eur J Pharmacol 130: 137-139.

El-Ghundi M, Fletcher PJ, Drago J, Sibley DR, O’Dowd BF, George SR (1999) Spatial learning deficit in dopamine $\mathrm{D}(1)$ receptor knockout mice. Eur J Pharmacol 383:95-106.

Fadok JP, Dickerson TM, Palmiter RD (2009) Dopamine is necessary for cue-dependent fear conditioning. J Neurosci 29:11089-11097.

Farb CR, Chang W, LeDoux JE (2010) Ultrastructural characterization of noradrenergic axons and Beta-adrenergic receptors in the lateral nucleus of the amygdala. Front Behav Neurosci 4:162.

Frankland KBJ, Paxinos G (1997) The mouse brain in stereotaxic coordinates. San Diego: Academic.

Friedman E, Jin LQ, Cai GP, Hollon TR, Drago J, Sibley DR, Wang HY (1997) D1-like dopaminergic activation of phosphoinositide hydrolysis is independent of D1A dopamine receptors: evidence from D1A knockout mice. Mol Pharmacol 51:6-11.

Gallagher M, Kapp BS, Musty RE, Driscoll PA (1977) Memory formation: evidence for a specific neurochemical system in the amygdala. Science 198:423-425.

Goh JW, Pennefather PS (1989) A pertussis toxin-sensitive G protein in hippocampal long-term potentiation. Science 244:980-983.

Gravius A, Barberi C, Schäfer D, Schmidt WJ, Danysz W (2006) The role of group I metabotropic glutamate receptors in acquisition and expression of contextual and auditory fear conditioning in rats - a comparison. Neuropharmacology 51:1146-1155.

Greba Q, Kokkinidis L (2000) Peripheral and intraamygdalar administration of the dopamine D1 receptor antagonist SCH 23390 blocks fearpotentiated startle but not shock reactivity or the shock sensitization of acoustic startle. Behav Neurosci 114:262-272.

Guarraci FA, Frohardt RJ, Kapp BS (1999) Amygdaloid D1 dopamine receptor involvement in Pavlovian fear conditioning. Brain Res 827:28 - 40 .

Hicks PE, Cavero I, Manoury P, Lefevre-Borg F, Langer SZ (1987) Comparative analysis of beta- 1 adrenoceptor agonist and antagonist potency and selectivity of cicloprolol, xamoterol and pindolol. J Pharmacol Exp Ther 242:1025-1034.

Holmes A, Hollon TR, Gleason TC, Liu Z, Dreiling J, Sibley DR, Crawley JN (2001) Behavioral characterization of dopamine D5 receptor null mutant mice. Behav Neurosci 115:1129-1144.

Inglis FM, Moghaddam B (1999) Dopaminergic innervation of the amygdala is highly responsive to stress. J Neurochem 72:1088-1094.

Iorio LC, Barnett A, Leitz FH, Houser VP, Korduba CA (1983) SCH 23390, a potential benzazepine antipsychotic with unique interactions on dopaminergic systems. J Pharmacol Exp Ther 226:462-468.

Izquierdo I, Dias RD (1983) The influence of adrenergic receptor antagonists on the amnestic and antiamnestic actions of adrenaline and tyramine. Psychopharmacology 80:181-183.

Izquierdo I, da Cunha C, Rosat R, Jerusalinsky D, Ferreira MB, Medina JH (1992) Neurotransmitter receptors involved in post-training memory processing by the amygdala, medial septum, and hippocampus of the rat. Behav Neural Biol 58:16-26.

Jin LQ, Goswami S, Cai G, Zhen X, Friedman E (2003) SKF83959 selectively regulates phosphatidylinositol-linked D1 dopamine receptors in rat brain. J Neurochem 85:378-386.

Joëls M, Baram TZ (2009) The neuro-symphony of stress. Nat Rev Neurosci 10:459-466.

Keiper M, Stope MB, Szatkowski D, Böhm A, Tysack K, Vom Dorp F, Saur O, Oude Weernink PA, Evellin S, Jakobs KH, Schmidt M (2004) Epac- and $\mathrm{Ca} 2+$-controlled activation of Ras and extracellular signal-regulated kinases by Gs-coupled receptors. J Biol Chem 279:46497-46508.

Lazzaro SC, Hou M, Cunha C, LeDoux JE, Cain CK (2010) Antagonism of lateral amygdala alphal-adrenergic receptors facilitates fear conditioning and long-term potentiation. Learn Mem 17:489-493.

Leonard SK, Anderson CM, Lachowicz JE, Schulz DW, Kilts CD, Mailman RB (2003) Amygdaloid D1 receptors are not linked to stimulation of adenylate cyclase. Synapse 50:320-333.

Lu YM, Jia Z, Janus C, Henderson JT, Gerlai R, Wojtowicz JM, Roder JC (1997) Mice lacking metabotropic glutamate receptor 5 show impaired learning and reduced CA1 long-term potentiation (LTP) but normal CA3 LTP. J Neurosci 17:5196-5205.

McGaugh JL, Roozendaal B (2002) Role of adrenal stress hormones in forming lasting memories in the brain. Curr Opin Neurobiol 12:205-210.

McGhee LL, Maani CV, Garza TH, Desocio PA, Gaylord KM, Black IH (2009) The effect of propranolol on posttraumatic stress disorder in burned service members. J Burn Care Res 30:92-97.

McOmish CE, Burrows EL, Howard M, Hannan AJ (2008a) PLC-betal knockout mice as a model of disrupted cortical development and plasticity: behavioral endophenotypes and dysregulation of RGS4 gene expression. Hippocampus 18:824-834.

McOmish CE, Burrows E, Howard M, Scarr E, Kim D, Shin HS, Dean B, van den Buuse M, Hannan AJ (2008b) Phospholipase C-betal knockout mice exhibit endophenotypes modeling schizophrenia which are rescued by environmental enrichment and clozapine administration. Mol Psychiatry 13:661-672.

Miserendino MJ, Sananes CB, Melia KR, Davis M (1990) Blocking of acquisition but not expression of conditioned fear- potentiated startle by NMDA antagonists in the amygdala. Nature 345:716-718.

Murchison CF, Zhang XY, Zhang WP, Ouyang M, Lee A, Thomas SA (2004) A distinct role for norepinephrine in memory retrieval. Cell 117:131-143.

Nielsen KS, Macphail EM, Riedel G (1997) Class I mGlu receptor antagonist 1-aminoindan-1,5-dicarboxylic acid blocks contextual but not cue conditioning in rats. Eur J Pharmacol 326:105-108.

Nugent NR, Christopher NC, Crow JP, Browne L, Ostrowski S, Delahanty DL (2010) The efficacy of early propranolol administration at reducing PTSD symptoms in pediatric injury patients: a pilot study. J Trauma Stress 23:282-287.

O'Carroll RE, Drysdale E, Cahill L, Shajahan P, Ebmeier KP (1999) Memory for emotional material: a comparison of central versus peripheral beta blockade. J Psychopharmacol 13:32-39.

O'Donnell SR, Wanstall JC (1980) Evidence that ICI 118, 551 is a potent, highly Beta 2-selective adrenoceptor antagonist and can be used to characterize Beta-adrenoceptor populations in tissues. Life Sci 27:671-677.

Ouyang M, Hellman K, Abel T, Thomas SA (2004) Adrenergic signaling plays a critical role in the maintenance of waking and in the regulation of REM sleep. J Neurophysiol 92:2071-2082.

Ouyang M, Zhang L, Zhu JJ, Schwede F, Thomas SA (2008) Epac signaling is required for hippocampus-dependent memory retrieval. Proc Natl Acad Sci 105:11993-11997.

Pape HC, Pare D (2010) Plastic synaptic networks of the amygdala for the acquisition, expression, and extinction of conditioned fear. Physiol Rev 90:419-463.

Poulin B, Butcher A, McWilliams P, Bourgognon JM, Pawlak R, Kong KC, Bottrill A, Mistry S, Wess J, Rosethorne EM, Charlton SJ, Tobin AB (2010) The M3-muscarinic receptor regulates learning and memory in a receptor phosphorylation/arrestin-dependent manner. Proc Natl Acad Sci 107:9440-9445.

Powis G, Seewald MJ, Gratas C, Melder D, Riebow J, Modest EJ (1992) Selective inhibition of phosphatidylinositol phospholipase $\mathrm{C}$ by cytotoxic ether lipid analogues. Cancer Res 52:2835-2840.

Qu LL, Guo NN, Li BM (2008) Beta1- and beta2-adrenoceptors in basolateral nucleus of amygdala and their roles in consolidation of fear memory in rats. Hippocampus 18:1131-1139.

Ramos M, Goñi-Allo B, Aguirre N (2005) Administration of SCH 23390 into the medial prefrontal cortex blocks the expression of MDMAinduced behavioral sensitization in rats: an effect mediated by 5 -HT2C receptor stimulation and not by D1 receptor blockade. Neuropsychopharmacology 30:2180-2191.

Rockman HA, Koch WJ, Lefkowitz RJ (2002) Seven-transmembranespanning receptors and heart function. Nature 415:206-212.

Rodrigues SM, Bauer EP, Farb CR, Schafe GE, LeDoux JE (2002) The group I metabotropic glutamate receptor mGluR5 is required for fear memory formation and long-term potentiation in the lateral amygdala. J Neurosci 22:5219-5229.

Rohrer DK, Desai KH, Jasper JR, Stevens ME, Regula DP Jr, Barsh GS, Bernstein D, Kobilka BK (1996) Targeted disruption of the mouse beta1adrenergic receptor gene: developmental and cardiovascular effects. Proc Natl Acad Sci 93:7375-7380.

Rudy JW, Matus-Amat P (2009) DHPG activation of group 1 mGluRs in BLA enhances fear conditioning. Learn Mem 16:421-425. 
Sadalge A, Coughlin L, Fu H, Wang B, Valladares O, Valentino R, Blendy JA (2003) alpha 1d Adrenoceptor signaling is required for stimulus induced locomotor activity. Mol Psychiatry 8:664-672.

Sahu A, Tyeryar KR, Vongtau HO, Sibley DR, Undieh AS (2009) D5 dopamine receptors are required for dopaminergic activation of phospholipase C. Mol Pharmacol 75:447-453.

Sara SJ (2009) The locus coeruleus and noradrenergic modulation of cognition. Nat Rev Neurosci 10:211-223.

Schafe GE, LeDoux JE (2000) Memory consolidation of auditory pavlovian fear conditioning requires protein synthesis and protein kinase $\mathrm{A}$ in the amygdala. J Neurosci 20:RC96.

Schutsky K, Ouyang M, Castelino CB, Zhang L, Thomas SA (2011) Stress and glucocorticoids impair memory retrieval via $\{$ beta\}2-adrenergic, Gi/ o-coupled suppression of cAMP signaling. J Neurosci 31:14172-14181.

Sibley DR, Monsma FJ Jr (1992) Molecular biology of dopamine receptors. Trends Pharmacol Sci 13:61-69.

Stein MB, Kerridge C, Dimsdale JE, Hoyt DB (2007) Pharmacotherapy to prevent PTSD: Results from a randomized controlled proof-of-concept trial in physically injured patients. J Trauma Stress 20:923-932.

Stratton KR, Cole AJ, Pritchett J, Eccles CU, Worley PF, Baraban JM (1989) Intrahippocampal injection of pertussis toxin blocks adenosine suppression of synaptic responses. Brain Res 494:359-364.

Tecott LH, Logue SF, Wehner JM, Kauer JA (1998) Perturbed dentate gyrus function in serotonin 5-HT2C receptor mutant mice. Proc Natl Acad Sci 95:15026-15031.

Thomas SA, Palmiter RD (1997) Disruption of the dopamine betahydroxylase gene in mice suggests roles for norepinephrine in motor function, learning, and memory. Behav Neurosci 111:579-589.
Thomas SA, Matsumoto AM, Palmiter RD (1995) Noradrenaline is essential for mouse fetal development. Nature 374:643-646.

Tully K, Bolshakov VY (2010) Emotional enhancement of memory: how norepinephrine enables synaptic plasticity. Mol Brain 3:15.

Undie AS, Weinstock J, Sarau HM, Friedman E (1994) Evidence for a distinct D1-like dopamine receptor that couples to activation of phosphoinositide metabolism in brain. J Neurochem 62:2045-2048.

Waelbroeck M, Taton G, Delhaye M, Chatelain P, Camus JC, Pochet R, Leclerc JL, De Smet JM, Robberecht P, Christophe J (1983) The human heart beta-adrenergic receptors. II. Coupling of beta 2-adrenergic receptors with the adenylate cyclase system. Mol Pharmacol 24:174-182.

Weeber EJ, Atkins CM, Selcher JC, Varga AW, Mirnikjoo B, Paylor R, Leitges M, Sweatt JD (2000) A role for the beta isoform of protein kinase C in fear conditioning. J Neurosci 20:5906-5914.

Wei F, Qiu CS, Liauw J, Robinson DA, Ho N, Chatila T, Zhuo M (2002) Calcium calmodulin-dependent protein kinase IV is required for fear memory. Nat Neurosci 5:573-579.

Weisstaub NV, Zhou M, Lira A, Lambe E, González-Maeso J, Hornung JP, Sibille E, Underwood M, Itohara S, Dauer WT, Ansorge MS, Morelli E, Mann JJ, Toth M, Aghajanian G, Sealfon SC, Hen R, Gingrich JA (2006) Cortical 5-HT2A receptor signaling modulates anxiety-like behaviors in mice. Science 313:536-540

Wilensky AE, Schafe GE, LeDoux JE (2000) The amygdala modulates memory consolidation of fear-motivated inhibitory avoidance learning but not classical fear conditioning. J Neurosci 20:7059-7066.

Xu M, Moratalla R, Gold LH, Hiroi N, Koob GF, Graybiel AM, Tonegawa S (1994) Dopamine D1 receptor mutant mice are deficient in striatal expression of dynorphin and in dopamine-mediated behavioral responses. Cell 79:729-742. 